\title{
Evaluation of antimicrobial activity of Ocimum tenuiflorum leaves on mechanical behavior of fabrics
}

\author{
Mehreen Ijaz ${ }^{1 *}$, Muhammad Maqsood ${ }^{2}$ and Muhammad Naveed ${ }^{3}$ \\ 1. Department of Home Economics, Lahore College for Women University-Pakistan \\ 2. Grey Marketing, Nishat Mills Pvt. Ltd-Pakistan \\ 3. Microtex Lab Lahore-Pakistan \\ *Corresponding author's email:mehreenijaz@hotmail.com \\ Citation
}

Mehreen Ijaz, Muhammad Maqsood and Muhammad Naveed. Evaluation of antimicrobial activity of Ocimum tenuiflorum leaves on mechanical behavior of fabrics. Pure and Applied Biology. Vol. 9, Issue 1, pp538-544. http://dx.doi.org/10.19045/bspab.2020.90059

\begin{tabular}{llll}
\hline \hline Received: 09/09/2019 & Revised: 27/11/2019 & Accepted: 02/12/2019 & Online First: 06/12/2019 \\
\hline \hline
\end{tabular}

\section{Abstract}

Microbial activity causes serious damage to living as well as non-living organisms. Many textile manufacturers are trying to provide better protection to their consumers against microbes and bacteria. Antibacterial finishing treatment is one of the latest achievements in this industry. There is a need to make use of natural herbs and plants rather than synthetic materials over the surface of fabrics to provide protection against certain physical, biological and chemical hazards. This study aimed at developing a textile finish by using leaves of natural plant named Ocimum tenuiflorum (tulsi). The effectiveness of developed finish was determined against its antimicrobial activity with Staphylococcus aureu and Escherchia coli on cotton, polyester, bamboo and a blend of polyester and cotton. The study was experimental in nature. Control and experimental groups of collected fabrics were formulated, where only experimental group was treated with the developed finish. Treated fabrics depicted their zone of inhibition from $35 \mathrm{~mm}$ to $56 \mathrm{~mm}$ and $28 \mathrm{~mm}$ to $52 \mathrm{~mm}$ for gram positive and gram negative bacteria respectively. It shows better protection against the growth of Staphylococcus aureus and Escherchia coli. Four mechanical characteristics such as tear strength, tensile strength, elongation and stiffness were evaluated to see the difference between treated and untreated fabrics to judge the efficiency of developed finish. The collected data was analyzed through One way Analysis of Variance (ANOVA). $\mathrm{P}$-value less than 0.05 suggest that there is a significant difference between experimental and control groups for their tested mechanical characteristics. It was observed that finish encapsulated the fiber structure completely and provided satisfactory protection against bacterial activity. Moreover, tested mechanical characteristics were also improved with the application of finish.

Keywords: Antimicrobial; Ocimum tenuifloru; Stiffness; Tear strength, Tensile strength

\section{Introduction}

There has been an increasing trend in producing consumer demanding products in textile industry such as comfortable clothing, wrinkle free apparel, water and fire repellent protective ensembles, soil and dust resistant clothes, antibacterial and antimicrobial costumes. Among all these, the development of antimicrobial finish through natural products is the most crucial for textile manufacturers [1].
Clothes are worn next to the skin. They protect the wearer from many physical, biological, chemical and environmental hazards. Performance of clothes largely depends on its certain functions such as protection against moisture, bacteria, flame or chemicals and resistance against soil, dust, water, wrinkles or creases etc. [2]. Cotton fiber is one of the most used textile fiber around the world. It has the most attraction for microbial activity, so it 
presents many challenges for the manufacturers to satisfy their consumer with many innovations. Moreover, cotton fiber is mostly used in medical textiles. So, it is very necessary to explore various techniques to control bacterial growth. That's why many finishing techniques are studied for better results in this category. Now-a-days consumer is also very much conscious about his/ her health [3]. These finishes in the form of laminations and coatings change the physical and mechanical characteristics of fabrics as well as can change the appearance, feel and look of the finished product [4].

Synthetic products can create a variety of effects in the field of dyeing, printing and finishing of textile goods, but at the same time, they present environmental problems as well as health issues. The concept of green consumerism is becoming very common globally. Apparel manufacturers have also diverted their attention to provide better products by using natural herbs and plants rather than synthetic materials $[5,6]$. Various plants are being used by the textile industry for developing natural dyes and obtaining extracts for making antimicrobial and water repellent finishes [7]. It has been investigated that almost all types of dyes obtained from natural sources such as plants, herbs, flowers and fruits are environment friendly and they do not create any skin irritation to their wearer $[8,9]$.

Antimicrobial finish comes under the category of chemical finishes. These are becoming more popular due to their relationship with health and wellbeing of the wearer [10]. This finish can be useful for apparel, sportswear, protective medical clothing and upholstery [11]. Components having antibacterial properties prevent the growth of bacteria and help to avoid their negative impact such as developing bad smell, yellowing of fabric and weakening of fiber [4]. The plants which contain natural property to kill bacteria have many therapeutic advantages, as these are not susceptible to harmful side effects. It has been investigated by many researchers that many parts of herbs and plants are useful against gram positive and negative bacteria [12].

As there are many plants available, there is a need to study the effect of each of these on various textile fibers against bacterial activity in order to determine the right end product. This study aimed at developing an antimicrobial natural finish by using Ocimum tenuiflorum (tulsi leaves) and then determining the effect of applied finish on selected mechanical properties of four different types of fabrics.

\section{Materials and methods}

This study was experimental in nature. Two groups of fabrics were formulated, control and experimental. Control group was not treated with the developed finish whereas antimicrobial finish was applied to the experimental group. Fabrics were labeled as 'treated' and 'untreated'. Then a comprehensive comparison was made between treated and untreated fabrics in order to evaluate the performance of applied finish. Manufacturing parameters of collected fabrics are given in (Table 1).

An antimicrobial finish was developed with the leaves of common herb known as Ocimum tenuiflorum (tulsi). These were collected, washed and dried under shadow. Rotten leaves were discarded and not included in the experiment. Dried leaves were grinded into fine powder. 50 grams of fine powder was mixed with $250 \mathrm{ml}$ of $80 \%$ Methanol. The solution was put in a container with a lid for 24 hours at room temperature so that Methanol takes into the solution completely. The solution was filtered out by muslin cloth first and then by using filters paper. Finally it was evaporated in order to concentrate the extract.

Prepared extract was applied on treated group of fabrics through pad-dry cure technique at $110^{\circ} \mathrm{C}$ for 2 minutes and cured at $120^{\circ} \mathrm{C}$ for about 3 minutes.

Antimicrobial activity was evaluated by following Qualitative method 147 [13]. This test method was employed in order to determine bacteria activity on selected 
fabrics. Rectangular specimens with the dimension of $25 \times 50 \mathrm{~mm}$ were cut from each sample. Sterilized nutrient agar was dispensed by pouring approximately $15 \mathrm{~mm}$ in each petri dish. Agar was turned into gel before inoculation. Inoculum was prepared with broth culture for 24 hours with distilled water. With sterile inoculation loop, Staphylococcus aureus and Escherchia coli were streaked out $(60 \mathrm{~mm}$ in length) with 5 parallel lines (Figure 1). A minimum of $10 \mathrm{~mm}$ space was left apart covering the surface of tested petri dish.
The test specimen was gently pressed across 5 lines by using sterilized spatula. Then all the prepared plates were incubated at $37{ }^{\circ} \mathrm{C}$ for 24 hours. The plates were observed for the bacterial inhabitation along the inoculum streaks of the sample (Figure 2). For a clear zone inhibition around the tested fabric, following equation was adopted.

$\mathrm{W}=\mathrm{T}-\mathrm{D} / 2$

Where,

$\mathrm{W}=$ width of clear zone

$\mathrm{T}=$ total diameter $($ fabric + clear zone

Table 1. Manufacturing parameters of collected fabrics

\begin{tabular}{|c|c|c|c|c|}
\hline Sample & Mass (GSM) & $\begin{array}{c}\text { Yarn Linear density } \\
\text { (warp) Tex system }\end{array}$ & $\begin{array}{c}\text { Yarn Linear density } \\
\text { (weft) Tex system }\end{array}$ & $\begin{array}{c}\text { Thread count } \\
\text { (in one inch) }\end{array}$ \\
\hline Cotton & 127 & 13.54 & 12.54 & 115 \\
\hline Polyester & 125 & 11.23 & 12.02 & 132 \\
\hline Bamboo & 115 & 11.68 & 12.56 & 105 \\
\hline Blend & 127 & 12.54 & 13.25 & 127 \\
\hline
\end{tabular}

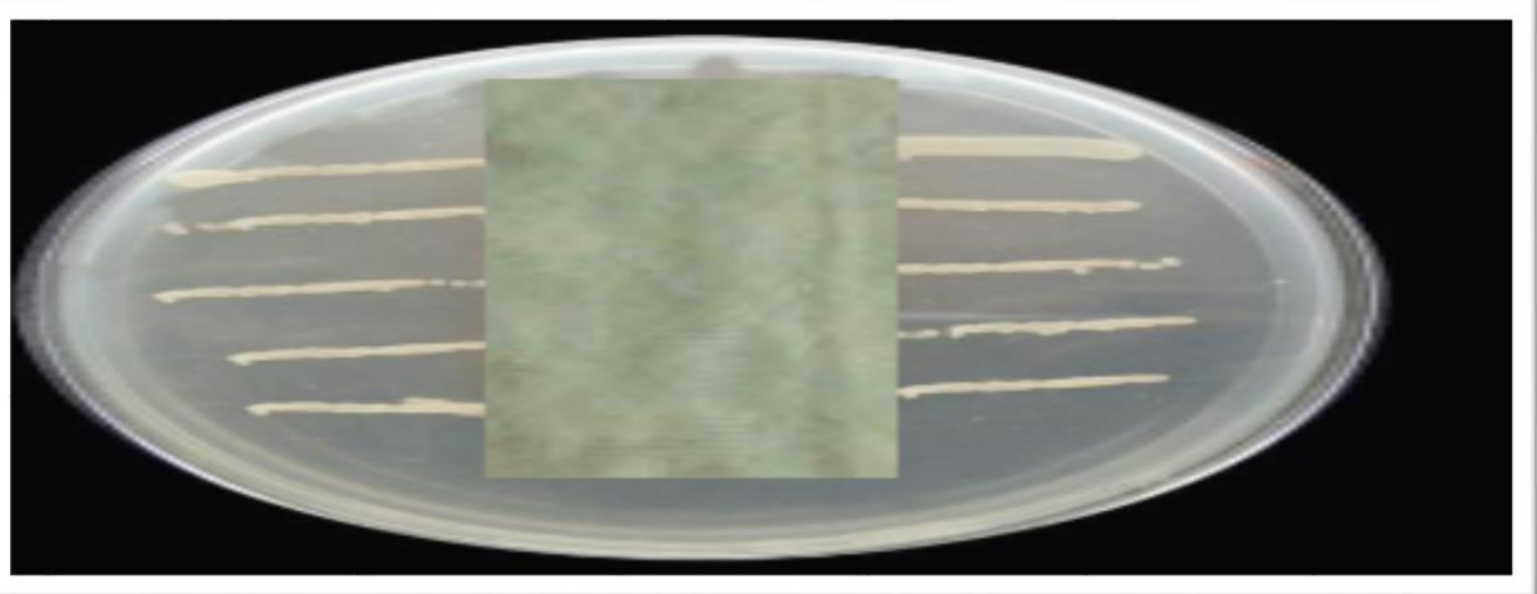

Figure 1. Prepared plate with microbial activity of E. Coli

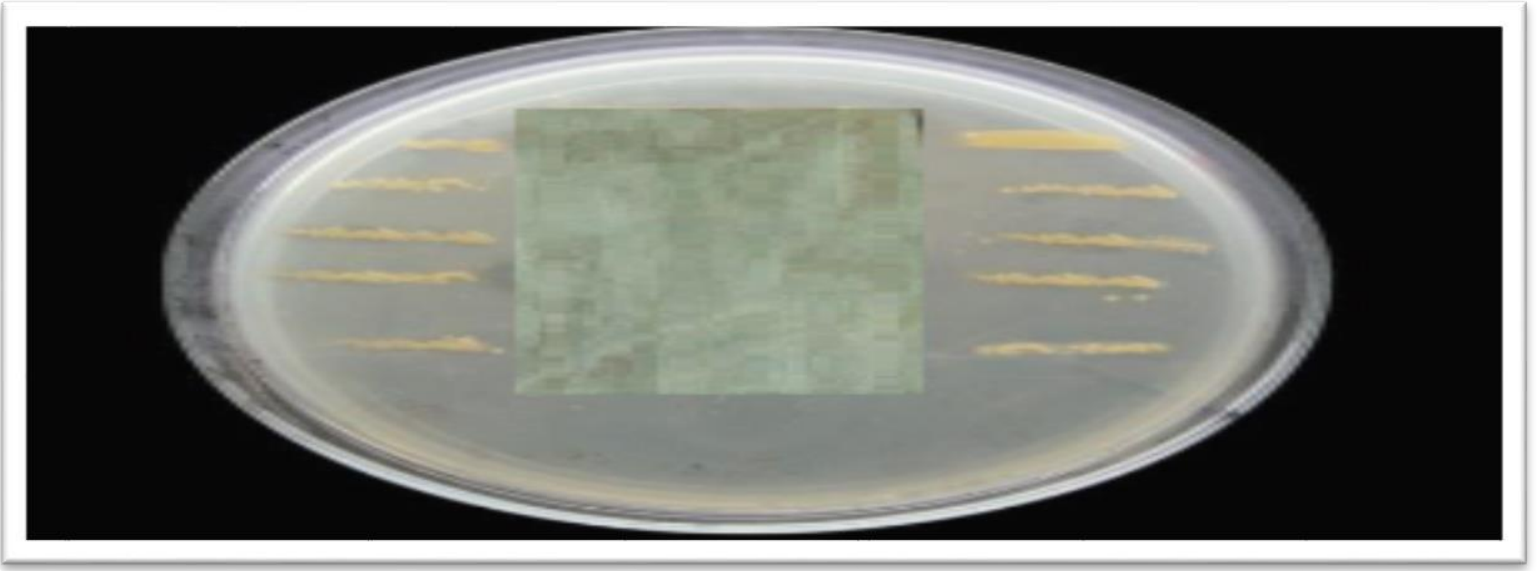

Figure 2. Prepared plate with microbial activity of S. aureus 


\section{Results and discussion}

The results depict a comprehensive comparison between treated (control group) and untreated (experimental group). One way Analysis of Variance (ANOVA) was employed to see the effect of newly developed finish on selected mechanical characteristics of all samples. P-value $\leq$ 0.05 was taken as significant.

It is clearly observed from (Table 2) that zone of inhibition ranges from 35 to 56 for gram positive and from 28 to 52 for gram negative selected bacteria. Whereas, bacteria growth can be easily identified with zone of inhibition ranging from 0 to 5 for all untreated group of samples. It can be said that the applied finish make the fabric resistant against the growth of bacteria and microbes. Antimicrobial agents help to kill the microbes present on the surface of tested fabrics as well as around their surface. There is a direction relationship between the size of the zone and microbial activity. It is generally observed that larger zone produces better antimicrobial activity and vice versa [14].

Many extracts from plant sources can serve as an effective tool against microbial activity [5]. Laminating cotton fabric with various parts of natural plants such as neem, pomegranate and turmeric helped to produce antibacterial properties [15]. Ocimum tenuiflorum belongs to Labiatae generic group of herbs. Its leaves contain $70 \%$ eugenol, $3 \%$ carvacrol, $20 \%$ methyl eugenol and small amount of $\beta$ caryophyllene and oleanolic acid. It has been studied that these ingredients serve excellent against certain bacteria, molds, mildews, microbes and insects. These compounds are supposed to minimize the bacterial growth upto $73 \%$ in various studies. Tulsi results better on cotton and cotton blended products in reducing the growth of bacteria $[16,17]$.

In a comparison of tested bacteria, high inhibition zone was detected for Staphylococcus aureus than Escherichia coli. The same phenomenon was studied by Vastrad and Byadgi [10]. It means that bacterial species belong to gram positive has high rate of inhibiting growth as compared to the gram negative. The results depicted that the treated sample slowdown the growth of gram-positive bacteria for about 92\% than untreated samples [18]. Application of natural source such as Aloe vera was tested for its antibacterial property on cotton fabric. It was investigated that tested sample presented 98\% reduction against the growth of $S$. aureus even after number of launderings [19]. One of the possible reasons was that antibacterial ingredients in tulsi leaves are strongly adhere to the surface of fabric in the form of bonds. These agents permeate through the cell wall of bacteria and damage it. It causes leakage in cellular structure and kills the bacteria [20].

Tear strength of samples is depicted in (Table 3). Untreated fabrics presented less strength as there was no coating applied on their surface. Ibrahim and Mahmoud [21] also studied that coated and laminated fabrics minimize spaces among yarns and make the structure more tight and compact which increases the tear and tensile strength of the end product. $\mathrm{P}$ value less than 0.05 depicts that there is a significant statistical difference between control (untreated) and experimental (treated) groups.

Table 4 depicted that there is a significant difference between treated and untreated samples for their tensile strength in both warp and weft directions, as the p-value is less than 0.05 . The similar results were observed in another study with application of chitosan on cotton fabric [22]. One of the possible reason of increase in tear and tensile strength is that the coating through pad dry technique add another layer on the surface of the fabrics and induce more strength in it [23].

Elongation of finished fabrics is very different from the untreated group of fabrics in both directions (Table 5). Nature of herb and plant, solvent used during extraction process, mordants used and especially the type of organism, kind of polymer and ration of herb added to the 
finish can greatly affect the bacterial inhibition on the fabric as well as its mechanical behavior in terms of many physical characteristics [15]. It was observed that more force was required to break the yarn in a sample than untreated sample. The results are very similar to another study conducted by Jaswal et al [24]. A study conducted by Doakhan et al [25] also showed that the presence of sericin on the fabric surface of cotton helped to increase the tensile strength in warp and weft direction.

Stiffness property of fabrics was evaluated after the application of developed finish in order to determine its performance for various end uses. It is clearly seen from significance value in (Table 6) that there is a difference in the stiffness of treated and untreated fabrics. In another study fabric treated with antimicrobial finish also increased the stiffness of fabrics both in warp and weft directions [25].

Table 2. Antimicrobial activity of collected fabrics

\begin{tabular}{|c|c|c|c|c|c|}
\hline \multirow{2}{*}{ Sample } & \multirow{2}{*}{ Bacterial species } & \multicolumn{2}{|c|}{$\begin{array}{c}\text { Zone of inhibition } \\
\text { (measured in mm) }\end{array}$} & \multicolumn{2}{c|}{ Growth observation } \\
\cline { 3 - 6 } & $\begin{array}{c}\text { Treated } \\
\text { sample }\end{array}$ & $\begin{array}{c}\text { Untreated } \\
\text { sample }\end{array}$ & $\begin{array}{c}\text { Treated } \\
\text { sample }\end{array}$ & $\begin{array}{c}\text { Untreated } \\
\text { sample }\end{array}$ \\
\hline Cotton & Staphylococcus aureus & 51 & 4 & No & Yes \\
\hline & Escherchia coli & 49 & 3 & No & Yes \\
\hline Polyester & Staphylococcus aureus & 35 & 2 & No & Yes \\
\hline & Escherchia coli & 28 & 0 & No & Yes \\
\hline Bamboo & Staphylococcus aureus & 56 & 5 & No & Yes \\
\hline & Escherchia coli & 52 & 4 & No & Yes \\
\hline Blend & Staphylococcus aureus & 42 & 1 & No & Yes \\
\hline & Escherchia coli & 30 & 0 & No & Yes \\
\hline
\end{tabular}

Table 3. Tear Strength of fabrics in warp and weft directions

\begin{tabular}{|c|c|c|c|c|c|c|}
\hline \multirow{2}{*}{$\begin{array}{c}\text { Sample } \\
\text { code }\end{array}$} & $\begin{array}{c}\text { Mean } \\
\text { difference }\end{array}$ & $\begin{array}{c}\text { Standard } \\
\text { error }\end{array}$ & $\begin{array}{c}\text { Significance } \\
\text { level }\end{array}$ & $\begin{array}{c}\text { Mean } \\
\text { difference }\end{array}$ & $\begin{array}{c}\text { Standard } \\
\text { error }\end{array}$ & $\begin{array}{c}\text { Significance } \\
\text { level }\end{array}$ \\
\cline { 2 - 7 } & \multicolumn{2}{|c|}{ Tear strength (Warp direction) } & \multicolumn{2}{|c|}{ Tear strength (Weft direction) } \\
\hline Cotton & -165.263 & 98.256 & 0.021 & -254.325 & 89.257 & 0.001 \\
\hline Polyester & -263.235 & 89.236 & 0.001 & -245.452 & 84.256 & 0.021 \\
\hline Bamboo & -435.625 & 99.325 & 0.012 & -337.526 & 85.124 & 0.024 \\
\hline Blend & -232.564 & 81.256 & 0.021 & -125.125 & 78.956 & 0.030 \\
\hline
\end{tabular}

Table 4. Tensile Strength of fabrics in warp and weft directions

\begin{tabular}{|c|c|c|c|c|c|c|}
\hline \multirow{2}{*}{$\begin{array}{c}\text { Sample } \\
\text { code }\end{array}$} & $\begin{array}{c}\text { Mean } \\
\text { difference }\end{array}$ & $\begin{array}{c}\text { Standard } \\
\text { error }\end{array}$ & $\begin{array}{c}\text { Significance } \\
\text { level }\end{array}$ & $\begin{array}{c}\text { Mean } \\
\text { difference }\end{array}$ & $\begin{array}{c}\text { Standard } \\
\text { error }\end{array}$ & $\begin{array}{c}\text { Significance } \\
\text { level }\end{array}$ \\
\cline { 2 - 7 } & \multicolumn{2}{|c|}{ Tensile strength (Warp direction) } & \multicolumn{2}{|c|}{ Tensile strength (Weft direction) } \\
\hline Cotton & -72.523 & 35.256 & 0.025 & -58.235 & 25.645 & 0.025 \\
\hline Polyester & -85.694 & 41.256 & 0.012 & -75.589 & 35.265 & 0.021 \\
\hline Bamboo & -89.565 & 51.256 & 0.032 & -77.254 & 25.985 & 0.021 \\
\hline Blend & -65.230 & 23.569 & 0.021 & -60.254 & 44.025 & 0.047 \\
\hline
\end{tabular}

Table 5. Elongation of fabrics in warp and weft directions

\begin{tabular}{|c|c|c|c|c|c|c|}
\hline \multirow{2}{*}{$\begin{array}{c}\text { Sample } \\
\text { code }\end{array}$} & $\begin{array}{c}\text { Mean } \\
\text { difference }\end{array}$ & $\begin{array}{c}\text { Standard } \\
\text { error }\end{array}$ & $\begin{array}{c}\text { Significance } \\
\text { level }\end{array}$ & $\begin{array}{c}\text { Mean } \\
\text { difference }\end{array}$ & $\begin{array}{c}\text { Standard } \\
\text { error }\end{array}$ & $\begin{array}{c}\text { Significance } \\
\text { level }\end{array}$ \\
\hline Elongation (Warp direction) & \multicolumn{2}{c|}{ Elongation (Weft direction) } \\
\hline Cotton & -564.256 & 80.215 & 0.000 & -456.235 & 78.320 & 0.001 \\
\hline Polyester & -652.215 & 59.965 & 0.013 & -492.562 & 45.236 & 0.012 \\
\hline Bamboo & -985.365 & 78.658 & 0.025 & -578.256 & 65.256 & 0.014 \\
\hline Blend & -569.212 & 58.652 & 0.023 & -578.361 & 55.657 & 0.034 \\
\hline
\end{tabular}


Table 6. Elongation of fabrics in warp and weft directions

\begin{tabular}{|c|c|c|c|c|c|c|}
\hline \multirow{2}{*}{$\begin{array}{c}\text { Sample } \\
\text { code }\end{array}$} & $\begin{array}{c}\text { Mean } \\
\text { difference }\end{array}$ & $\begin{array}{c}\text { Standard } \\
\text { error }\end{array}$ & $\begin{array}{c}\text { Significance } \\
\text { level }\end{array}$ & $\begin{array}{c}\text { Mean } \\
\text { difference }\end{array}$ & $\begin{array}{c}\text { Standard } \\
\text { error }\end{array}$ & $\begin{array}{c}\text { Significance } \\
\text { level }\end{array}$ \\
\cline { 2 - 7 } & \multicolumn{2}{|c|}{ Stiffness (Warp direction) } & \multicolumn{2}{c|}{ Stiffness (Weft direction) } \\
\hline Cotton & -1.521 & 0.254 & 0.021 & -0.876 & 0.121 & 0.003 \\
\hline Polyester & -0.765 & 0.432 & 0.012 & -0.534 & 0.215 & 0.001 \\
\hline Bamboo & -5.254 & 0.876 & 0.021 & -2.534 & 0.325 & 0.012 \\
\hline Blend & -2.324 & 0.123 & 0.021 & -1.564 & 0.125 & 0.020 \\
\hline
\end{tabular}

\section{Conclusion}

Ocimum tenuiflorum leaves were used to develop an antimicrobial finish for four different types of fabrics. Some of the selected characteristics were assessed before and after finishing treatment. It was concluded that there was no bacterial growth seen on treated fabrics, whereas, a prominent growth was observed with all untreated fabrics. The results explored that tulsi leaves help in $100 \%$ reduction against microorganisms. So, this plant can be useful in adopting natural approach in textile finishing for making fabric antibacterial in apparel, upholstery and especially medical clothing. This study can provide a framework for the textile manufacturers to use tulsi leaves as finishing treatment for various types of fabrics.

\section{Authors' contributions}

Conceived and designed the experiments: M Ijaz \& M Maqsood, Performed the experiments: $\mathrm{M}$ Ijaz \& $\mathrm{M}$ Naveed, Analyzed the data: M Ijaz \& M Naveed, Contributed materials/ analysis/ tools: $\mathrm{M}$ Ijaz \& M Maqsood, Wrote the paper: M Ijaz.

\section{References}

1. Sathianarayanan MP, Bhat NV, Kokate SS \& Walunj VE (2010). Antibacterial finish for cotton fabric from herbal products. Retrieved from http://nopr.niscair.res.in/bitstream/123 456789/7662/3/IJFTR\%2035(1)\%2050 -58.pdf (assessed 05-03-19).

2. Hooda S, Khambra K, Yadav N, \& Sikka VK. (2013). Effect of Laundering on Herbal Finish of Cotton. Inter J Tex Fashion Tech 3(4): 35-42
3. Thilagavathi G \& Kannaian T (2010). Combined antimicrobial and aroma finishing treatment for cotton, using micro encapsulated geranium (Pelargonium graveolens L'Herit. Ex Ait.) leaves extract. Retrieved from http://nopr.niscair.res.in/bitstream/123 456789/10279/1/IJNPR\%201(3)\%203 48-352.pdf (assessed 03-02-19).

4. Khurshid MF, Ayob M, Asad M, \& Shah SNH (2015). Assessment of ecofriendly natural antimicrobial textile finish extracted from aloe vera and neem plants. Fibres Text East Eur 23 (6): 120-123.

5. Lee YH, Hwang EK \& Kim HD (2009). Colorimetric assay and antibacterial activity of cotton, silk, and wool fabrics dyed with peony, pomegranate, clove, coptis chinenis and gallnut extracts. Materials 2(1): 10-21.

6. Ali NF \& El-Mohamedy RSR (2011). Eco-friendly and protective natural dye from red prickly pear (Opuntia Lasiacantha Pfeiffer) plant. $J$ Saudi Chem Soc 15(3): 257-261.

7. Chengaiah B, Rao KM, Kumar KM, Alagusundaram $\mathrm{M} \&$ Chetty CM (2010). Medicinal importance of natural dyes a review. Inter J Pharm Tech Res 2(1): 144-154.

8. Siva R (2007). Status of natural dyes and dye-yielding plants in India. Curr Sci India 92(7): 105-115

9. Sathianarayanan MP, Chaudhari BM \& Bhat NV (2011). Development of durable antibacterial agent from banajwain seed (Thymus serpyllum) for cotton fabric. Ind J Fibre Tex Res 36(3): 234-241. 
10. Vastrad VJ \& Byadgi SA (2018). Ecofriendly antimicrobial finishing of cotton fabric using plant extracts. Int $J$ Curr Micro App Sci 7(2): 284-292.

11. Varesano A, Vineis C, Aluigi A, \& Rombaldoni F (2011). Antimicrobial polymers for textile products. Sci micro pathogen: Comm Curr Res Tech Adv 5(3): 99-110.

12. Jothi, D. (2009). Experimental study on antimicrobial activity of cotton fabric treated with aloe gel extract from Aloe vera plant for controlling the Staphylococcus aureus (bacterium). Afr J of Microbiol Res 3(5): 228-232.

13. AATCC 147 (2016). Antimicrobial. Parallel Streak Method, American Association of Textile Chemists and Colorists.

14. Gupta D \& Laha A. (2007). Antimicrobial activity of cotton fabric treated with Quercus infectoria extract. Retrieved from http://nopr.niscair.res.in/bitstream/123 456789/408/1/FTR\%2032(1)\%20(200 7)\%2088-92.pdf (assessed 15-06-19).

15. Mahesh S, Manjunatha AH, Reddy V \& Kumar G (2011). Studies on antimicrobial textile finish using certain plant natural products. Proc Adv Biotech Pharm. Sci

16. Ates DA \& Turgay O (2003). Antimicrobial activities of various medicinal and commercial plant extracts. Turk J Biol 27(3): 157-162.

17. Balamurugan GK, \& Babuskin $S$ (2018). Antimicrobial coating of cotton twill tape with neem oil, eucalyptus oil and tulsi oil for medicinal application. Curr Sci India. 115(4): 779-782.
18. Ravindra KB \& Murugesh BK (2016). Study of antimicrobial properties of fabrics treated with Ocimum sanctum $\mathrm{L}$ (tulsi) extract as a natural active agent. $J$ Nat Fibers 13(5): 619-627.

19. Joshi M, Ali SW, Purwar R \& Rajendran S (2009). Ecofriendly antimicrobial finishing of textiles using bioactive agents based on natural products. Retrieved http://nopr.niscair.res.in/handle/123456 789/6083

20. Rajendran R, Radhai R, Kotresh TM, \& Csiszar E (2013). Development of antimicrobial cotton fabrics using herb loaded nanoparticles. Carbohydr polym 91(2): 613-617.

21. Ibrahim GE \& Mahmoud ER (2013). Achieving optimum scientific standards for producing fabrics suitable for protecting against hazardous chemical liquids. Life Sci J 10(1): 342-353.

22. Bonin LE. (2008). Durable and reusable antimicrobial textiles, Masters Thesis, Uni of Louisiana, Lafayette, USA.

23. Doakhan S, Montazer M, Rashidi A, Moniri R \& Moghadam MB (2013). Influence of sericin/TiO2 nanocomposite on cotton fabric: Part 1. Enhanced antibacterial effect. Carbohydr Polym 94(2): 737748.

24. Jaswal P, Preet A, Simrana GG (2017). Antimicrobial activity of herbal treated cotton fabric. Inter Res J Eng Tech 4(8): 39-43.

25. Dhiman G, \& Chakraborty JN (2015). Antimicrobial performance of cotton finished with triclosan, silver and chitosan. Fash Tex J 2(1): 13-15. 